\title{
PERBANDINGAN PENGETAHUAN TENTANG MANAJEMEN DIABETES MELITUS PADA MAHASISWA TAHAP SARJANA DAN PROGRAM PENDIDIKAN PROFESI DOKTER (P3D) FAKULTAS KEDOKTERAN UNIVERSITAS SAM RATULANGI MANADO
}

\author{
${ }^{1}$ Agustinus Rihando Rumbino \\ ${ }^{2}$ Karel Pandelaki \\ ${ }^{2}$ Yuanita Asri Langi
}

\author{
${ }^{1}$ Kandidat Skripsi Fakultas Kedokteran Universitas Sam Ratulangi Manado \\ ${ }^{2}$ Bagian Ilmu Penyakit Dalam Fakultas Kedokteran Universitas Sam Ratulangi Manado \\ Email: agus.rihando@gmail.com
}

\begin{abstract}
Diabetes mellitus (DM) is a health problem that increases the number of events globally. Medical doctor as the first line in the treatment of diabetes are required to have good knowledge about its management. Students of the Faculty of Medicine, University of Sam Ratulangi trained to become medical doctor were had good knowledge about management of diabetes melitus. The problem is what is the description of knowledge about DM management on undergraduate students and professional education programs of medical doctor (P3D) students. Objective: The study was to compared the level of knowledge about DM management among undergraduate students and P3D students of Faculty of Medicine, Sam Ratulangi University. Method: This study is a descriptive analytical with quantitative approach involving 80 subjects were selected based consecutive sampling and was answered the questionnaire about knowledge of DM management. Results: The subjects knowledge about DM management in undergraduate students from 40 subject result 1 subject $(2.5 \%)$ are included in the category of good knowledge, 7 subject (17.5\%) had moderate knowledge and 32 subjects $(80 \%)$ are included of low knowledge. The subjects of P3D students result 3 subjects (7.5\%) including good knowledge category, 25 subjects (62.5\%) were categorized moderate knowledge and 12 subjects (30\%) is low knowledge category. Conclusion: Knowledge level about DM management undergraduate student is still low. P3D student knowledge level about diabetes management is classified as moderate. Knowledge level about diabetes management on P3D students is better than undergraduate students.
\end{abstract}

Keywords: Knowledge, medical students, management of diabetes mellitus.

\begin{abstract}
Abstrak: Diabetes Melitus (DM) merupakan masalah kesehatan yang angka kejadiannya meningkat secara global. Dokter umum sebagai lini pertama dalam penanganan DM dituntut untuk memiliki pengetahuan yang baik tentang manajemennya. Mahasiswa Fakultas Kedokteran Universitas Sam Ratulangi Manado yang dididik untuk menjadi dokter haruslah memiliki pemahaman yang baik tentang manajemen Diabetes Melitus. Permasalahannya adalah bagaimana gambaran pengetahuan mengenai manajemen DM pada mahasiswa tahap sarjana dan tahap program pendidikan profesi dokter (P3D). Tujuan: Penelitian ini bertujuan untuk membandingkan tingkat pengetahuan mengenai manajemen DM pada mahasiswa tahap sarjana dan tahap P3D Fakultas Kedokteran Universitas Sam Ratulangi Manado. Metode: Penelitian ini bersifat analitik deskriptif dengan pendekatan kuantitatif melibatkan 80 responden yang menjawab kuesioner pengetahuan mengenai manajemen DM. Hasil: Dari 40 responden mahasiswa tahap sarjana 1 responden (2,5\%) termasuk dalam kategori pengetahuan baik, 7 responden $(17,5 \%)$ termasuk kategori sedang dan 32 reponden $(80 \%)$ termasuk kategori rendah. Pada 40 responden mahasiswa tahap profesi (P3D) diketahui 3 responden $(7,5 \%)$ termasuk kategori pengetahuan baik, 25 responden (62,5\%) termasuk kategori sedang dan 12 responden (30\%)
\end{abstract}


adalah kategori pengetahuan rendah. Simpulan: Tingkat pengetahuan mahasiswa tahap sarjana mengenai manajemen DM masih rendah. Tingkat pengetahuan mahasiswa P3D mengenai manajemen DM masih tergolong sedang. Tingkat pengetahuan manajemen DM mahasiswa P3D lebih baik dibanding mahasiswa tahap sarjana.

Kata kunci: Pengetahuan, mahasiswa kedokteran, manajemen diabetes melitus.

Diabetes Melitus (DM) merupakan masalah kesehatan yang angka kejadiannya meningkat secara global. Data International Diabetes Federation (IDF) tahun 2012, lebih dari 371 juta masyarakat dunia menderita diabetes, setengah dari jumlah tersebut tidak terdiagnosa, dan 4,8 juta orang meninggal dunia akibat diabetes. Lebih dari 471 juta US Dolar dihabiskan untuk pengobatan diabetes. Diperkirakan pada tahun 2030 akan terdapat 550 juta penderita diabetes, $60 \%$ berasal dari Asia. ${ }^{1,2}$

Dalam penanganan masalah tersebut diperlukan kerjasama dari berbagai pihak baik pemerintah maupun swasta mulai dari promosi kesehatan, pencegahan, dan pengobatan diabetes. Tenaga kesehatan memiliki peran penting dalam pengelolaan penyakit DM yaitu sebagai pengelola pasien DM. Dokter umum adalah lini pertama dalam pengelolaan penyakit Diabetes Melitus. Dokter umum haruslah memiliki kemampuan dengan kompetensi 4A sesuai dengan Standar Kompetensi Dokter Indonesia (SKDI) dari Konsil Kedokteran Indonesia yaitu lulusan dokter mampu membuat diagnosis klinik dan melakukan penatalaksanaan penyakit tersebut secara mandiri dan tuntas. ${ }^{3}$

Sebagai salah satu Institusi pendidikan yang sedang mempersiapkan calon dokter umum, Fakultas Kedokteran Universitas Sam Ratulangi Manado telah menerapkan Kurikulum Berbasis Kompetensi (KBK). Kurikulum Berbasis bersifat student centered yang menekankan pada fasilitasi pembelajaran mahasiswa. Sejak tahap sarjana mahasiswa telah dibekali dengan pengetahuan tentang Diabetes Melitus yaitu pada modul Gangguan Metabolik di semester 4, dengan waktu kuliah Diabetes Melitus hanya 2 jam efektif dilanjutkan dengan diskusi tutorial. Sedangkan pada tahap profesi mahasiswa telah diperhadapkan langsung dengan pasien-pasien DM.,
Gambaran tingkat pengetahuan mengenai manajemen DM pada mahasiswa tahap sarjana dan tahap P3D menjadi salah satu acuan untuk menilai kesiapan mahasiswa sebelum menjadi dokter umum yang menjadi lini pertama penanganan penyandang DM.

\section{METODE}

Penelitian ini bersifat analitik deskriptif dengan pendekatan kuantitatif melibatkan 80 responden yang menjawab kuesioner pengetahuan mengenai manajemen DM. Penelitian ini dilakukan di Kampus Fakultas Kedokteran Universitas Sam Ratulangi \& RSUP Prof.Dr.R.D. Kandou Manado. Penelitian ini dilakukan selama 3 bulan mulai dari bulan November 2013 sampai Januari 2014. Populasi target dari penelitian ini adalah Mahasiswa Fakultas Kedokteran Universitas Sam Ratulangi Manado. Populasi terjangkau penelitian ini adalah Mahasiswa semester V dan VII tahap sarjana tahun 2013 yang telah mendapat teori tentang Diabetes Melitus dan mahasiswa tahap pendidikan profesi dokter (P3D) Fakultas Kedokteran Universitas Sam Ratulangi. Data dianalisis menggunakan software pengolahan data yaitu SPSS versi 20. Dalam analisis data di hitung skor tertinggi di tiap kelompok dan dikategorikan menjadi tingkat pengetahuan baik jika skor kuesioner $\geq 80$, dikategorikan sedang jika skornya 60-79 dan dikategorikan rendah bila skor kuesioner $<60$.

\section{HASIL}

Dari 80 responden yang telah berpartisipasi dalam penelitian ini dan memiliki hasil valid didapatkan responden tahap P3D memiliki nilai yang lebih baik dibanding tahap sarjana. Usia dan angkatan responden tidak menjadi acuan dalam uji 
Rumbino, Pandelaki, Langi; Perbandingan Pengetahuan tentang Manajemen...

statistik data penelitian ini. Hasil didasarkan pada skor kuesioner.

Tabel 1. Distribusi frekuensi berdasarkan karakteristik responden $(\mathrm{n}=80)$

\begin{tabular}{ccc}
\hline Karakteristik & Frekuensi & \% \\
\hline Jenis Kelamin & & \\
Laki-laki & 37 & 46 \\
Perempuan & 43 & 54 \\
Angkatan & & \\
2008 & 25 & 31 \\
2009 & 15 & 19 \\
2010 & 20 & 25 \\
2011 & 20 & 25 \\
Tahap Pendidikan & & \\
Sarjana & 40 & 50 \\
P3D & 40 & 50 \\
\hline
\end{tabular}

Pada tabel data demografis responden mahasiswa tahap sarjana berdasarkan jenis kelamin adalah 19 laki-laki dan 21 perempuan, sedangkan pada mahasiswa P3D adalah 21 laki-laki dan 19 perempuan.

Data berdasarkan angkatan pada mahasiswa tahap sarjana adalah 20 responden angkatan 2011 dan 20 responden dari angkatan 2010, sedangkan pada mahasiswa P3D diperoleh data 19 responden adalah angkatan 2008 dan 21 responden merupakan angkatan 2009.

Tabel 2. Distribusi pengetahuan manajemen DM berdasarkan hasil kuesioner $(\mathrm{n}=80)$

\begin{tabular}{llcc}
\hline & Frekuensi & \% \\
\hline Tahap Sarjana & & \\
Baik & 1 & 2,5 \\
& Sedang & 7 & 17,5 \\
\multicolumn{1}{c}{ Kurang } & 32 & 80 \\
& KDD & & \\
& Baik & 3 & 7,5 \\
\multicolumn{1}{c}{ Sedang } & 15 & 62,5 \\
& Kurang & 20 & 30 \\
\hline
\end{tabular}

Berdasarkan hasil penelitian dari 40 responden mahasiswa tahap sarjana didapatkan 32 responden (80\%) termasuk dalam kategori pengetahuan yang kurang sedangkan 7 responden $(17,5 \%)$ termasuk dalam pengetahuan yang sedang dan hanya 1 responden $(2,5 \%)$ yang termasuk kategori pengetahuan yang baik.
Dari 32 responden yang memiliki tingkat pengetahuan kurang, 16 responden (50\%) berasal dari angkatan 2011 sama dengan jumlah responden dari angkatan 2010, hal ini menunjukkan bahwa tidak ada perbedaan bermakna berdasarkan angkatan. Pada 7 responden tingkat pengetahuan sedang diperoleh 4 responden (57\%) berasal dari angkatan 2011 dibandingkan dengan 3 responden (43\%) dari angkatan 2010, hal ini juga menunjukkan bahwa tidak ada perbedaan bermakna antara angkatan 2011 dan 2010. Sedangkan pada 1 responden yang memiliki tingkat pengetahuan baik berasal dari angkatan 2010, dalam hal ini tidak memiliki nilai perbedaan yang signifikan dikarenakan jumlah responden yang sedikit.

Data menunjukkan 12 responden yang memiliki tingkat pengetahuan yang kurang 8 responden (66\%) berasal dari angkatan 2009, sedangkan 4 responden (34\%) berasal dari angkatan 2008, ini menujukkan ada perbedaan berdasarkan angkatan. Pada 25 responden yang memiliki tingkat pengetahuan sedang, 12 responden (48\%) berasal dari angkatan 2008 sedangkan sisanya 13 responden (52\%) adalah dari angkatan 2009, hal ini menunjukkan perbedaan. Pada 3 responden yang yang memiliki tingkat pengetahuan baik semuanya berasal dari angkatan 2008.

Tabel 3. Distribusi perbandingan pengetahuan manajemen DM mahasiswa tahap sarjana dan P3D $(n=80)$

\begin{tabular}{cll}
\hline Kategori & Sarjana & P3D \\
\hline Baik & $1(1,25 \%)$ & $3(3,75 \%)$ \\
Sedang & $7(8,75 \%)$ & $25(31,25 \%)$ \\
Kurang & $32(40 \%)$ & $12(15 \%)$ \\
\hline
\end{tabular}

Berdasarkan tabel diatas menunjukkan perbedaan yang signifikan dimana hasil kuesioner menunjukkan bahwa mahasiswa tahap P3D memiliki tingkat pengetahuan yang lebih baik (31,5\%) dibandingkan mahasiswa tahap sarjana (8,75\%). 


\section{BAHASAN}

Berdasarkan hasil kuesioner penelitian persentase responden mahasiswa tahap sarjana didapatkan $80 \%$ termasuk dalam kategori pengetahuan kurang sedangkan $17,5 \%$ termasuk dalam pengetahuan sedang dan hanya 2,5\% yang termasuk kategori pengetahuan baik.

Tingkat pengetahuan yang rendah dari mahasiswa tahap sarjana (80\%) mungkin dipengaruhi oleh proses berpikir yang hanya sampai tahap mengingat dan memahami saja dan belum sampai pada tahap proses aplikasi. ${ }^{6}$

Selain itu proses pembelajaran, suasana dan mahasiswa lain juga bisa mempengaruhi pemahaman mahasiswa terhadap materi DM dimana mahasiswa menerima materi dalam kelas besar yang terdiri dari 150 orang bisa mempengaruhi konsenterasi belajar. Antusiasme mahasiswa dalam pembahasan materi DM pada kelas tutorial juga bisa menentukan penerimaan pengetahuan tentang manajemen DM secara maksimal.

Tingkat pengetahuan yang sedang $(17,5 \%)$ dan baik (2,5\%) dipengaruhi oleh kemandirian mahasiswa dalam mencari bahan pembelajaran terkait baik textbook, jurnal, video bisa meningkatkan pengetahuan manajemen DM. Pada hasil kuesioner menunjukkan ada perbedaan yang bermakna antara persentase responden mahasiswa P3D dengan persentase responden mahasiswa tahap sarjana, diketahui $13 \%$ responden memiliki tingkat pengetahuan kurang, dan 62,5\% responden memiliki tingkat pengetahuan sedang serta hanya $7,5 \%$ responden memiliki tingkat pengetahuan baik.

Terdapatnya perbedaan tingkat pengetahuan mungkin dipengaruhi oleh keadaan mahasiswa P3D yang telah belajar dari kehidupan nyata, dimana pembelajaran berdasarkan pasien-pasien yang ditangani, sehingga dengan dipraktekkannya ilmu tersebut semakin menambah wawasan berpikir ketika harus bersikap dalam manajemen DM.

Mengaplikasikan pengetahuan tentang manajemen DM merupakan bagian dari tahap berpikir yang bisa meningkatkan tingkat pengetahuan mahasiswa. ${ }^{7}$

Hal ini didukung oleh penelitian yang dilakukan Sagar AS di Libya (2010) bahwa dari 325 sampel mahasiswa tahun terakhir memiliki tingkat pengetahuan diabetes yang cukup baik. $^{7}$

\section{SIMPULAN}

1.Tingkat pengetahuan mahasiswa tahap sarjana mengenai manajemen Diabetes Melitus masih rendah.

2.Tingkat pengetahuan mahasiswa P3D mengenai manajemen Diabetes Melitus pada umumnya masih tergolong sedang.

3.Tingkat pengetahuan mahasiswa P3D mengenai manajemen Diabetes Melitus lebih baik dibandingkan dengan mahasiswa tahap sarjana.

\section{DAFTAR PUSTAKA}

1.Kozlovski P, Foley J,Qing S, Lukashevich V, Kothny W. Vildaglipin-insulin combination improves glycemic control in Asians with type 2 diabetes. World Journal of Diabetes. 2013 August 15;4(4):152.

2. International Diabetes Federation. Diabetes atlas update 2012. Available from : www.idf.org/diabetesatlas/5e/Update2012.htm 1 [cited 2013 Sep 20]

3.Konsil Kedokteran Indonesia. Standar kompetensi dokter Indonesia. Jakarta,2012.

4. Nurfitri Bustaman, Runinda Pradnyamita, Citra Ayu Aprilia, Wahyukarno. Hubungan kurikulum pendidikan tahap sarjana terhadap kompetensi mahasiswa pada tahap profesi di rumah sakit pendidikan. The Indonesian Journal of Medical Education. 2012 November;1(3):176-7.

5.Fakultas Kedokteran Universitas Sam Ratulangi. Buku pegangan mahasiswa modul gangguan metabolik. Manado,2013.

6. A Model of Learning Objectives based on A Taxonomy for Learning, Teaching, and Assessing: A Revision of Bloom's Taxonomy of Educational Objectives. Available from : www.celt.iastate.edu/pdf/RevisedBloomsHand out

7.Sagar AS. Practical Diabetes Knowledge of Final Year Medical Students in Tripoli,Libya. Ibnosina Journal of Medicine and Biomedical Science. 2011 January 01. 